\title{
SEASONAL WATER TEMPERATURE VARIABILITY OF SPRINGS FROM POROUS SEDIMENTS IN GRYŻYNKA VALLEY, WESTERN POLAND
}

\author{
AnNa Maria SZCZucińSKA \\ Institute of Physical Geography and Environmental Planning, Adam Mickiewicz University in Poznań, Poland \\ HIERONIM WASIELEWSKI \\ Gryżyna Landscape Park, Zawisze, Poland
}

Manuscript received: June 15, 2013

Revised version: July 5, 2013

SZCZUCiŃSKA A.M., WASIELEWSKI H., 2013. Seasonal water temperature variability of springs from porous sediments in Gryżynka Valley, western Poland. Quaestiones Geographicae 32(3), Bogucki Wydawnictwo Naukowe, Poznań, pp. 111-117. 3 tables, 3 figs. DOI 10.2478/quageo-2013-0019, ISSN 0137-477X.

AвSTRACT. This paper discusses fluctuations in spring water temperature and its correlation to climate and aquifer characteristics. Data from nine springs in the Gryżynka River catchment (Polish Plain) were taken monthly (November 2005 to October 2010). The springs examined in this study are characterised by significant thermal inertia in contrast to air temperature, that is expressed in small temperature amplitudes that range from $1.3^{\circ} \mathrm{C}$ to $2.3^{\circ} \mathrm{C}$. The average temperature of the springs is about $9^{\circ} \mathrm{C}$. The research proved that observed groundwater temperature variations on the surface resulted mainly from atmospheric conditions, especially air temperature. The highest water temperatures (up to $10^{\circ} \mathrm{C}$ ) were observed during late summer and early autumn, and the lowest temperature $\left(7.7^{\circ} \mathrm{C}\right)$ was observed at the end of the winter period. The range of spring water temperature variability may reflect amount of water contribution from local water recharge in the spring vicinity.

KEY WORDS: springs, spring water temperature, groundwater monitoring, Poland

Address of the corresponding author: Anna M. Szczucinska, Institute of Physical Geography and Environmental Planning, Adam Mickiewicz University in Poznań, ul. Dzięgielowa 27, 61-680 Poznań, Poland, e-mail: szana@amu.edu.pl

\section{Introduction}

Analysing the groundwater that emerges in springs was found to be an easy and fast tool research method (Aldwell, Burdon 1986), then the springs should be considered important elements of an environmental monitoring network (Bender et al. 2001). Measuring the temperature of spring water aids the assessment of heat flow from the surface to the groundwater (Bundschuh 1993, Manga 1998, Musgrove et al. 2010) and of the influence of geothermal heat on spring water temperature (Manga, Kirchner 2004, Leaver, Unsworth 2007). Such measurement also assists in the determination of residence time in underground and the direction of its circulation (James et al. 2000, Becker et al. 2004, Baena et al. 2009). Bundschuh (1995) suggested applying water temperature 
measurements as one of the methods to assess potential groundwater contamination, a concept that is also suggested in Malard and Chapuis (1995) and Wampler and Sisson (2010). Groundwater temperature measurements have been used to analyse the effects of urbanisation and climate change on the underground environment (Taniguchi, Uemura 2005, Taylor, Stefan 2009). Other potential applications of spring water temperature measurements include assessment of use of groundwater resources for drinking, industrial purposes and balneology (Manga 2001).

Springs located in areas that consist of sedimentary porous rocks (sand, gravel, etc.) are much less studied than the springs that originate in fissured rocks or karst formations. However, the field studies that were conducted on the topic in recent decades proved that they occur more frequently than had previously been assumed and that they serve as an important hydrographic element where they exist (e.g. Bender et al. 2001, Szczucińska, Marciniak 2008, Chełmicki 2011, Szczucińska in press). For instance, in areas that were shaped by ice sheets during the Last Glacial Maximum and are covered with thick glacial and glacifluvial deposits, the share of the spring water discharge in the river reaches 30\% (Szczucińska 2009). However, the thermal properties of the water that emerges from them have been little studied.This paper presents the seasonal and inter-annual temperature variability of spring water that flows from porous media (sediments) to discuss the natural factors that affect these variations and to assess the utility of spring water temperature monitoring in areas with porous sedimentary aquifers.

\section{Study area}

This paper studies springs that are located in the Gryżynka River catchment, which is part of the Lubuska Plateau in the western Polish Lowlands (Fig. 1). The catchment area is approximately $77.5 \mathrm{~km}^{2}$, and approximately $76 \%$ of the area is covered by forests, with the remainder covered by crop fields $(16 \%)$ or village buildings and water bodies (8\%). Gryżynka river source is located at a height of $75 \mathrm{~m}$ a.s.l. The river joins the Odra River after $17 \mathrm{~km}$ at a height of $42 \mathrm{~m}$ a.s.l. The main feature of the basin is the 30-m-deep tunnel valley of the Gryżynka river, which drains the catchment area. The valley cuts through sandur deposits (mainly sand and gravel) and reaches the groundwater level, thus resulting in numerous groundwater outflows. Altogether, 354 groundwater outflows have been documented in the basin, and these have been ordered into 70 groups. The spring density, calculated as number of groups, is 0.95 per square kilometre (Szczucińska 2009). The basic characteristics of the studied springs are presented in Table 1.

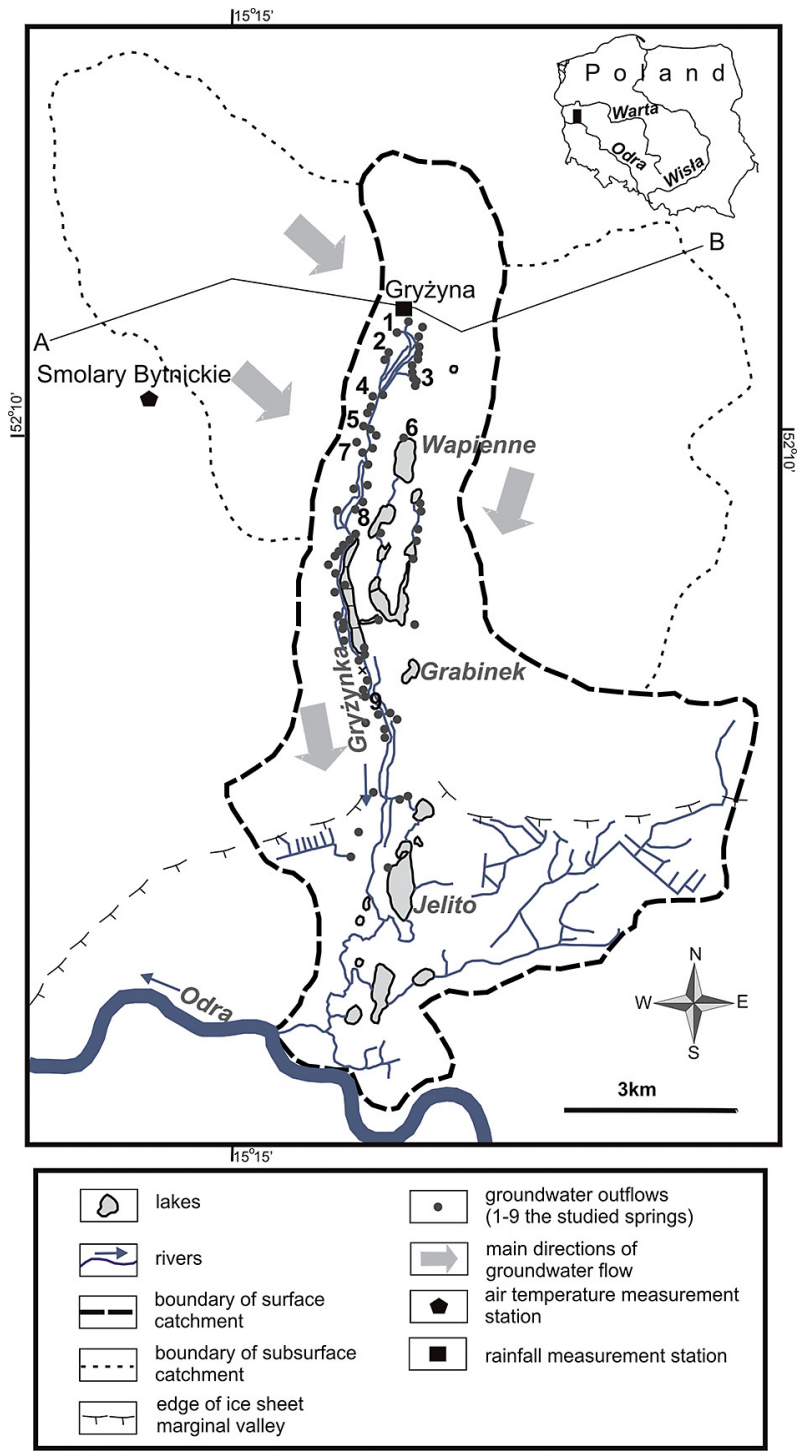

Fig. 1. Locations of the springs in the Gryżyna-Grabin Tunnel Valley. The monitored springs are marked with numbers 1 to 9 . The inset shows the location of the study area in Poland. Transect Line A-B marks the location of the hydro-geological cross-section that is presented in Fig. 2 
Table 1. Basic characteristics of the springs. Average discharge and specific electrical conductivity (SpC) after Szczucińska (2009)

\begin{tabular}{|c|c|c|l|l|l|}
\hline Spring & $\begin{array}{c}\text { Average dis- } \\
\text { charge } \mathbf{d m}^{3} \mathbf{s}^{-1}\end{array}$ & $\mathbf{S p C} \boldsymbol{\mu} \mathbf{S c m}^{-1}$ & Form of water outflow & $\begin{array}{c}\text { Morphological } \\
\text { position }\end{array}$ & $\begin{array}{c}\text { Land-use of area in the } \\
\text { neighborhood of spring }\end{array}$ \\
\hline 1 & 43 & 422 & descending-ascending & at the slope base & village, forest \\
\hline 2 & 0.6 & 524 & descending & at the slope base & village, forest \\
\hline 3 & 0.9 & 474 & descending & at the slope base & village, forest \\
\hline 4 & 22 & 371 & descending-ascending & at the slope base & fields, forest \\
\hline 5 & 6.5 & 485 & descending & at the slope base & fields, forest \\
\hline 6 & 3.3 & 427 & descending & at the slope base & tourist resort, forest \\
\hline 7 & 0.5 & 348 & descending & at the slope base & forest \\
\hline 8 & 2 & 340 & descending & at the slope base & forest \\
\hline 9 & 0.6 & 263 & descending & at the slope base & forest \\
\hline
\end{tabular}

The groundwater that emerges from these springs flows through Pleistocene sediments, the thickness of which varies from $30 \mathrm{~m}$ in the southern part of the catchment to $150 \mathrm{~m}$ in the western part (Fig. 2). These sediments are composed of intercalated sands, gravel, glacial tills, silts and glacilacustrine clays. The variable arrangement of the permeable and semi-permeable beds within the Quaternary sediments results in an aquifer with complex hydro-geological properties, with hydraulic conductivity values in range of $2 \cdot 10^{-6}$ to $9 \cdot 10^{-5}\left[\mathrm{~m} \mathrm{~s}^{-1}\right]$ (Szczucińska 2009).

The study area is located in a transitional zone between the oceanic and continental temperate climate zone. The average annual temperature is $8.2^{\circ} \mathrm{C}$ (Woś 1999), and the average annual precipitation is about $630 \mathrm{~mm}$ (Graf 2006).

\section{Methods}

The temperature of the spring water was measured once a month between November 2005 and October 2010 in nine springs using a calibrated electronic thermometer ETI 2001, with $0.1^{\circ} \mathrm{C}$ accuracy. Measurements were taken at the point of water outflow from the ground.

The average monthly air temperatures were obtained from the automatic meteorological station in Smolary Bytnickie, which is located $8 \mathrm{~km}$

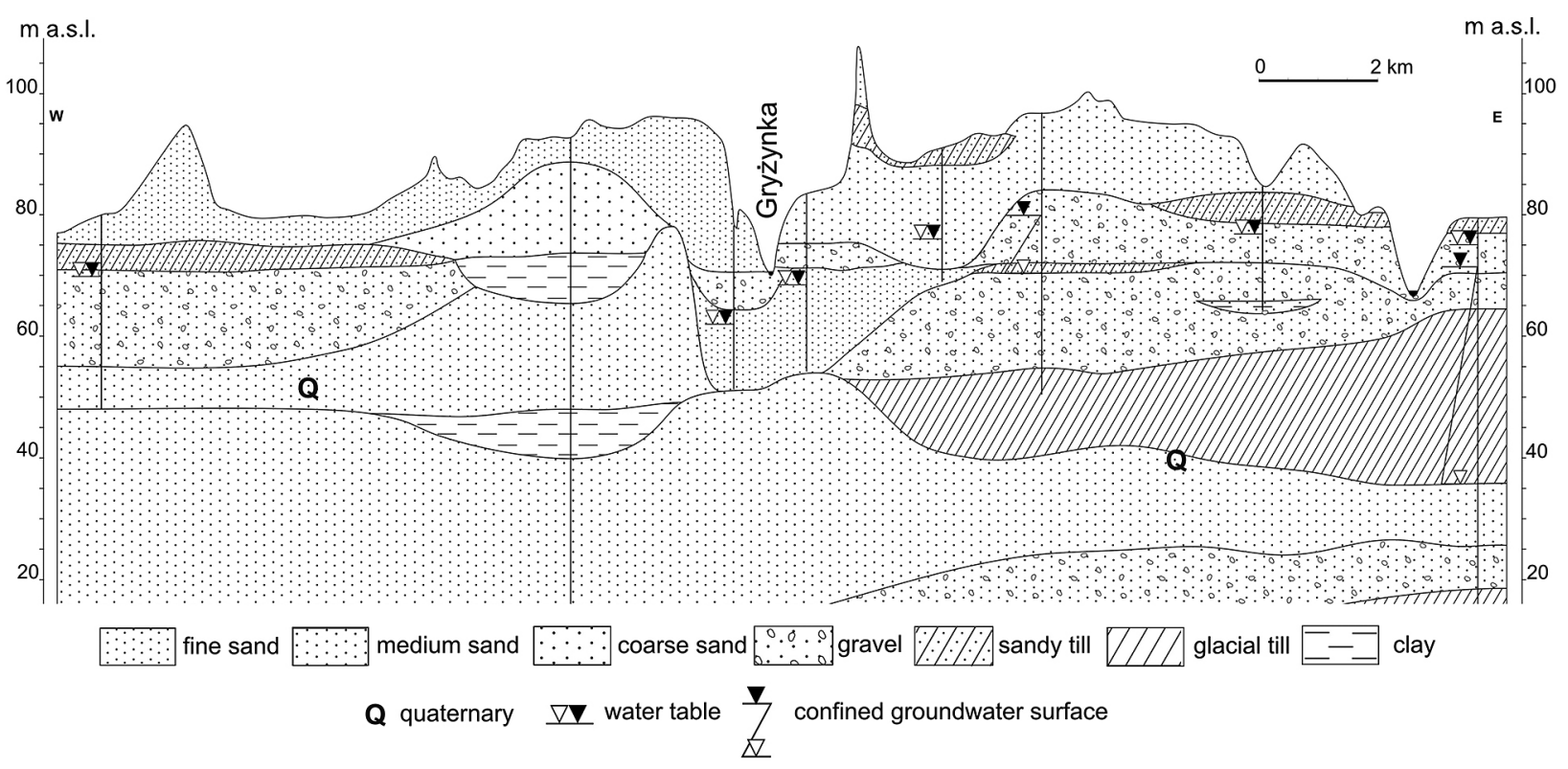

Fig. 2. Hydro-geological cross-section along Line A-B (Fig. 1) through the Gryżyna-Grabin Tunnel Valley 
from the border of the Gryżynka River's surface catchment (Fig. 1). The station is at $77 \mathrm{~m}$ a.s.l. in extra-urban area.

Monthly precipitation data was acquired from the precipitation meteorological station of the Institute of Meteorology and Water Management (IMGW), located at an altitude $80 \mathrm{~m}$ a.s.l., in Gryżyna village (Fig. 1). The precipitation was measured by Hellmann Precipitation Recorder, that was set $1 \mathrm{~m}$ above ground surface.

\section{Results}

The water temperatures that were measured in the nine springs are presented in Fig. 3A. The average water temperature of particular springs

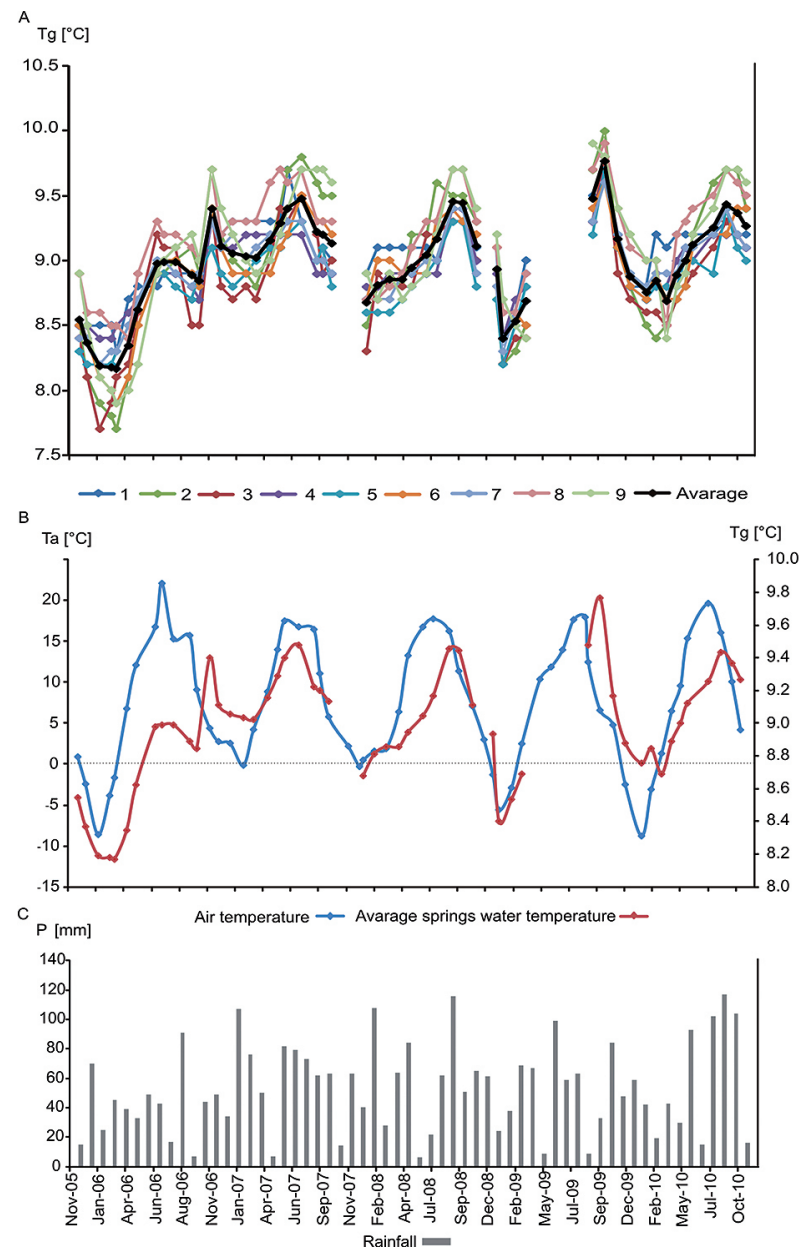

Fig. 3. A) Monthly average water temperature of the nine monitored springs (numbered 1-9 in Fig. 1) and the average temperature of all spring waters between November 2005 and October 2010; B) the monthly average water temperature of the nine analysed springs compared to the monthly average air temperature varied between $8.8^{\circ} \mathrm{C}$ and $9.2^{\circ} \mathrm{C}$ (Table 2). The amplitude of the average temperature the seven springs did not exceed $2^{\circ} \mathrm{C}$ (Table 2). The lowest temperature, $7.7^{\circ} \mathrm{C}$, was observed in Springs 2 and 3 in March and January 2006, respectively, and the highest temperature $\left(10.0^{\circ} \mathrm{C}\right)$ was measured in Spring 2 in September 2009. The lowest average water temperature in the nine springs was observed between January and March 2006 and was equal to $8.2^{\circ} \mathrm{C}$. The highest average spring water temperatures varied from $9.4^{\circ} \mathrm{C}$ to $9.8^{\circ} \mathrm{C}$ and were observed from August to October in 2008, 2009 and 2010. In 2006, the highest average water temperatures were measured in November, and in 2007, the highest temperatures occurred in June and July. Their values were $9.4^{\circ} \mathrm{C}, 9.4^{\circ} \mathrm{C}$ and $9.5^{\circ} \mathrm{C}$, respectively.

The average air temperature during the study period (Fig. 3B), measured at the meteorological station was $7.4^{\circ} \mathrm{C}$ and it was $0.8^{\circ} \mathrm{C}$ lower than the average temperature in the last three decades. In 2006, 2009 and 2010, the lowest average temperatures were recorded in the coldest month (January) at $-8.6,-5.6$ and $-8.8^{\circ} \mathrm{C}$, respectively. Winters in 2007 and 2008 were considerably warmer. The lowest monthly average air temperatures in 2007 were observed in February $\left(-0.1^{\circ} \mathrm{C}\right)$ and December $\left(-0.3^{\circ} \mathrm{C}\right)$, and in 2008 in January $\left(-0.5^{\circ} \mathrm{C}\right)$. The average temperature of the summer months (July-September) was $17.7^{\circ} \mathrm{C}$ and $16.1^{\circ} \mathrm{C}$ in 2006 and 2009, respectively, but the summer season of 2007 exhibited a colder average air temperature at $14.8^{\circ} \mathrm{C}$.

The total annual precipitation (Fig. 3C) during the study period varied from $478 \mathrm{~mm}$ in 2006 to 723 $\mathrm{mm}$ in 2008, and the average total annual precipitation for Poland is $600 \mathrm{~mm}$ (Woś 1999). In years 2006 to 2009, the precipitation was equal during the cold and warm halves of the year. In the year

Table 2. Summary of the maximum, minimum and mean water temperature, as well as the maximum observed amplitude for the monitored springs in period November 2005 and October 2010

\begin{tabular}{|l|c|c|c|c|c|c|c|c|c|}
\hline Spring No. & $\mathbf{1}$ & $\mathbf{2}$ & $\mathbf{3}$ & $\mathbf{4}$ & $\mathbf{5}$ & $\mathbf{6}$ & $\mathbf{7}$ & $\mathbf{8}$ & $\mathbf{9}$ \\
\hline Tmax & 9.8 & 10 & 9.8 & 9.7 & 9.7 & 9.6 & 9.6 & 9.9 & 9.9 \\
\hline Tmin & 8.3 & 7.7 & 7.7 & 8.4 & 8.2 & 7.9 & 8.2 & 8.4 & 7.9 \\
\hline Amplitude & 1.5 & 2.3 & 2.1 & 1.3 & 1.5 & 1.7 & 1.4 & 1.5 & 2.0 \\
\hline Mean & 9.1 & 9.0 & 8.8 & 8.9 & 8.8 & 8.9 & 8.9 & 9.2 & 9.1 \\
\hline
\end{tabular}


2010 nearly twice as much rainfall was during the warm half of the year as during the cold half.

\section{Discussion}

\subsection{Characteristics of the springs based on their water temperature}

Water temperature is one of the basic parameters of groundwater classification. According to commonly used spring water classification system, the long-term average air temperature is compared with the average spring water temperature in a given region (Hackett 1998). Under this approach, the spring waters of the Gryżynka basin are classified as "normal waters" because their average temperature is approximately $9^{\circ} \mathrm{C}$ and is similar to the long-term average air temperature of the region $\left(8.2^{\circ} \mathrm{C}\right.$ ) (Woś 1999).

The small amplitudes in the spring water temperatures, in the range from $1.3^{\circ} \mathrm{C}$ to $2.3^{\circ} \mathrm{C}$, may demonstrate that the springs are charged with waters, drained from regional voluminous groundwater aquifers (Fig. 1). It is confirmed by available preliminary results of water isotopes measurements suggesting that the residence time of water in the aquifers is from 30 (Spring 1 and 5) to about 100 (Spring 9) years (Szczucińska 2009) and moderate hydraulic conductivity values in the aquifer sediments. Manga (1999) analysed the temperatures of spring waters from fractured aquifer rocks in Oregon and observed small $\left(0.1-0.2^{\circ} \mathrm{C}\right)$ monthly amplitudes in spring water temperatures. He also concluded that the springs drained waters from large aquifers and remained in the subsurface for at least a decade.

\subsection{The relationship between spring water temperature and air temperature}

The main factor that affected the water temperature of the springs was the type of groundwater that drained from the aquifer. The low variation of water temperatures (amplitudes in range of $1.3^{\circ} \mathrm{C}$ to $2.3^{\circ} \mathrm{C}$ ) suggest that the majority of the spring water may comes from waters that are confined to the deeper part of the aquifer, which is located beneath the zone of season- al temperature changes. However, as Figure 3B shows, the minor fluctuations in the spring water temperature generally follow the pattern of average monthly air temperature changes, with a correlation coefficient of 0.62 at the 0.001 significance level (p). Thus, the variations in the spring water temperature reflect a secondary contribution from the subsurface waters, which are subject to seasonal air temperature changes. The spring water temperature may be also affected by direct contact with the atmosphere or by mixing with the precipitation waters that infiltrate toward the springs from nearby areas. This explanation is in agreement with seasonal changes in water hydrochemistry of the studied springs (Szczucińska et al. 2010).

Cross-correlation coefficients were calculated to determine whether the atmospheric air temperature was reflected in the short term (e.g., due to direct warming or cooling due to contact with air or water), or with some delay (e.g., due to the transit time in the subsurface area). The analyses considered correlations of spring water temperature with air temperature in the same month ( $\mathrm{r} 0)$, in the previous month (one step; $r 1$ ), two months prior (two steps; r2) and three months prior (three steps; r3). Table 3 depicts the detailed results of the cross-correlation. The significant heat capacity of the vadose zone causes the water temperature to change with a 1-2 month delay to the change in the average air temperature. For sev-

Table 3. Correlations and cross-correlations of spring water temperatures and air temperatures (r0: of the same month as the water temperature, $r 1$ - of the month before, r2 - of the two months before, r3 - of the three months before). $\mathrm{r} 0$ - correlation coefficient r1-r3 - cross-correlation coefficients with a step from 1 to 3 . The highest values of cross-correlation coefficients are underlined

\begin{tabular}{|c|c|c|c|c|}
\hline Spring No. & r0 & r1 & r2 & r3 \\
\hline 1 & 0.44 & $\underline{0.45}$ & 0.41 & \\
\hline 2 & 0.69 & $\underline{0.82}$ & 0.78 & \\
\hline 3 & 0.68 & $\underline{0.75}$ & 0.65 & \\
\hline 4 & 0.49 & $\underline{0.55}$ & 0.52 & \\
\hline 5 & 0.61 & $\underline{0.68}$ & 0.6 & \\
\hline 6 & 0.55 & 0.72 & $\underline{0.77}$ & 0.64 \\
\hline 7 & 0.59 & $\underline{0.64}$ & 0.57 & \\
\hline 8 & 0.61 & $\underline{0.73}$ & 0.69 & \\
\hline 9 & 0.46 & 0.73 & $\underline{0.85}$ & 0.76 \\
\hline
\end{tabular}


en of the springs, the strongest correlation was found between water temperature and the average air temperature of the previous month (from 0.64 to $0.82, p=0.05$ ). For two other springs, the strongest correlation was with the air temperature two months prior $(0.77$ and $0.85, p=0.05)$. The weakest correlations and cross-correlations between the spring water temperature and the air temperature were observed in Springs 1 and 4. This may be related to the location of the water outflows; in both cases, the springs are situated at the foot of slopes that are approximately $10 \mathrm{~m}$ in height, so even water that recharges directly above the springs requires a relatively longer period of time to reach them.

\subsection{The influence of precipitation on spring water temperature}

In the case of springs that drain sedimentary porous media, the reaction to precipitation has rarely been recorded (Moniewski 2004), and in the present study, as seen in Figure 3C, the amount of precipitation shows no clear correlation with the spring water temperatures. The correlation coefficient between monthly precipitation and spring water temperature is 0.3 at the 0.05 significance level, but the type of precipitation is of great importance. For example, during brief rainfall events, most of the water flows down the slopes directly into the Gryżynka River. During longer periods of rainfall, however, the temperature and the otherwise stable discharge of spring water may change. For example, in October 2009, the average spring water temperature increased due to the high temperatures of the summer months and likely due to the greater amount of precipitation during that month. The influence of precipitation is likely because the rainfall occurred at a time when average daily temperatures were relatively high. For example, October 7 , the average temperature reached $16.8^{\circ} \mathrm{C}$, although the monthly average temperature for October was $6.6^{\circ} \mathrm{C}$. However, in order to identify spring water reaction to the precipitation (e.g. change in discharge, water temperature, electrical conductivi- ty), more frequent monitoring needed to be carry out, especially in the period after rainfall.

\section{Conclusions}

Temperature data taken from selected springs that drain sedimentary porous aquifers in the temperate climatic zone demonstrated that:

- Groundwater that emerged from the springs revealed very small temperature amplitudes due to their significant thermal inertia in contrast to air temperature. The average temperature measured in the springs was approximately $9^{\circ} \mathrm{C}$ and was comparable to the air temperature of the region.

- The observed seasonal spring water temperature changes were only $1^{\circ} \mathrm{C}$ to $2^{\circ} \mathrm{C}$ and followed variations in air temperature. The changes resulted probably from the admixture of shallow subsurface groundwater, direct warming and/or cooling at the spring and long-term rainfall periods.

- This research showed that groundwater temperature provides valuable information about not only the subsurface environment but also about the water sources. The higher amplitudes of spring water temperatures may reflect bigger contribution from local recharge in the vicinity of springs. This observation may be useful in defining the protection zones for springs used for water intake.

- The monthly measurements of spring water temperature show general variation. However, the future studies should include daily or hourly measurements which may be useful for identification of the rate of reaction of spring water to the local recharge.

\section{Acknowledgements}

This study was supported by the Polish Ministry of Science and Higher Education through research grant No. 3673/T02/2007/32 and No. NN306 035 040. I cordially thank all who helped me during the research, particularly prof. Marek Marciniak for discussions and support. 


\section{References}

Aldwell C.R., Burdon D.J., 1986. Temperature of infiltration and groundwater. In: Proceedings of Conjuctive Water Use Symposium. Budapest, IAHS Publ. no. 156.

Baena C.L., Andreo B., Mudry J., Cantos F.C., 2009. Groundwater temperature and electrical conductivity as tools to characterize flow patterns in carbonate aquifers: The Sierra de las Nieves karst aquifer, southern Spain. Hydrogeology Journal 17: 843-853.

Becker M.W., Georgian T., Ambrose H., Siniscalchi J., Fredrick K., 2004. Estimating flow and flux of ground water discharge using water temperature and velocity. Journal of Hydrology 296: 221-233.

Bender S., Einsiedl F., Wohnlich S., 2001. Scheme for development of monitoring networks for springs in Bavaria, Germany. Hydrogeology Journal 9: 208-216.

Bundschuh J., 1993. Modeling annual variations of spring and groundwater temperatures associated with shallow aquifer systems. Journal of Hydrology 142: 427-444.

Bundschuh J., 1995. Assessing the contamination potential of groundwater using its temporal temperature variations. In: Proceedings of Models for Assessing and Monitoring Groundwater Quality Symposium. Boulder, IAHS Publ. no. 227.

Chełmicki W., Jokiel P., Michalczyk Z., Moniewski P., 2011. Distribution, discharge and regional characteristics of springs in Poland. Episodes 34: 244-256.

Graf R., 2006. Komentarz do mapy hydrologicznej w skali 1:50 000. N-33-139-A Lubrza. (Coments to hydrological map 1:50 000. N-33-139-A Lubrza). GEOMAT, Poznań.

James E.R., Manga M., Rose T.P., Hudson G.B., 2000. The use of temperature and the isotopes of $\mathrm{O}, \mathrm{H}, \mathrm{C}$, and noble gases to determine the pattern and spatial extent of groundwater flow. Journal of Hydrology 237: 100-112.

Leaver J.D., Unsworth C.P., 2007. System dynamics modeling of spring behavior in the Orakeikorako geothermal field, New Zealand. Geothermics 36: 101-114.

Malard F., Chapuis R., 1995. Temperature logging to describe the movement of sewage-polluted surface water infiltrating into a fractured rock aquifer. Journal of Hydrology 173: 191-217.

Manga M., 1998. Advective heat transport by low temperature discharge in the Oregon Cascades. Geology 26: 799 802.
Manga M., 1999. On the timescales characterizing groundwater discharge at springs. Journal of Hydrology 219: 56-69.

Manga M., 2001. Using springs to study groundwater flow and active geologic processes. Annual Reviews in Earth Planetary Sciences 29: 201-228.

Manga M., Kirchner J.W., 2004. Interpreting the temperature of water at cold springs and the importance of gravitational potential energy. Water Resources Research. 40, W05110, DOI 10.1029/2003WR002905.

Moniewski P., 2004. Źródła okolic Łodzi (Springs nearby city of Łódź). Acta Geographica Lodziensia 87: 1-140.

Musgrove M., Stern L.A., Banner J.L., 2010. Springwater geochemistry at Honey Creek State Natural Area, central Texas: Implications for surface water and groundwater interaction in a karst aquifer. Journal of Hydrology 388: 144-156.

Szczucińska A.M., 2009. Wypływy wód podziemnych w Rynnie Gryżyńsko-Grabinskiej (Groundwater outflows in the Gryżyna-Grabin tunnel valley). Wyd. Bogucki, Poznań, 117 pp.

Szczucińska A.M., in press. Spatial distribution and hydrochemistry of springs and seepage springs in the Lubuska Upland of western Poland. Hydrology Research. Doi: 10.2166/nh.2013.249.

Szczucińska A.M., Marciniak M., 2008. Zones of groundwater outflow in the Gryzyna-Grabin tunnel valley as an example of groundwater outflows on the Polish Plain. In: G. Migiros, G. Stamatis, G. Stournaras (eds.), Proceedings of 8th International Hydrogeological Congress of Greece. The Geological Society of Greece, Athens: 863-868.

Szczucińska A.M., Siepak M., Zioła-Frankowska A., Marciniak M, 2010. Seasonal and spatial changes of metal concentrations in groundwater outflows from porous sediments in the Gryżyna-Grabin Tunnel Valley in western Poland. Environmental Earth Sciences 61: 921-930.

Taniguchi M., Uemura T., 2005. Effects of urbanization and groundwater flow on the subsurface temperature in Osaka, Japan. Physics of the Earth and Planetary Interiors 152: 305-313.

Taylor C.A., Stefan H.G., 2009. Shallow groundwater temperature response to climate change and urbanization. Journal of Hydrology 375: 601-612.

Wampler P.J., Sisson A.J., 2010. Spring flow, bacterial contamination, and water resources in rural Haiti. Environmental Earth Science. DOI: 10.1007/s12665-010-0645-9.

Woś A., 1999. Klimat Polski (Climate of Poland). PWN, Warszawa, $130 \mathrm{pp}$. 